DOI: 10.2478 /ausp-2020-0003

\title{
Language Revival and Educational Reform in Ireland and Hungary: Douglas Hyde, Patrick Pearse, Arthur Griffith
}

\author{
Eglantina REMPORT \\ Eötvös Loránd University (Budapest, Hungary) \\ remport.eglantina@btk.elte.hu
}

\begin{abstract}
Patrick Pearse's editorial in the journal of the Gaelic League, $A n$ Claidheamh Soluis, is the starting point of this essay that explores Irish perceptions of the Hungarian language question as it panned out during the early nineteenth century. Arthur Griffith's The Resurrection of Hungary: A Parallel for Ireland (1904), to which Pearse refers in his editorial, is the focal point of the discussion, with the pamphlet's/book's reference to Count István Széchenyi's offer of his one-year land revenue to further the cause of the Hungarian language at the Hungarian Diet of Pozsony (present-day Bratislava) in 1825. Széchenyi's aspirations are examined in the essay in comparison with the ideals of Baron József Eötvös, Minister of Religious and Educational Affairs $(1848 ; 1867-71)$, in order to indicate the strong connection that existed between the question of language use and religious and educational matters in Hungary. Similar issues were discussed in Ireland during the nineteenth century, providing further points of reference between Ireland and Hungary in the late nineteenth/early twentieth century. Finally, the debate between language revivalists and reformists is studied in some detail, comparing the case of Hungary between the 1790s and the 1840 s with that of Ireland between the 1890s and the 1920s.
\end{abstract}

Keywords: education, language reform, Patrick Pearse, Arthur Griffith, Douglas Hyde, The Resurrection of Hungary, Ireland

\section{Introduction}

Patrick Pearse wrote a glowing review of Arthur Griffith's The Resurrection of Hungary in the Gaelic League (Conradh na Gaeilge) journal, An Claidheamh Soluis (The Sword of Light), in the autumn of 1904. Pearse began his editorial with the following words: "We do not know that there has been published in Ireland in our time any book in English more important than 'The Resurrection of Hungary", $(1904,7)$. This was so, argued Pearse, because "it crystallises into a national policy 
the doctrines which during the past ten years have been preached in Ireland by the apostles of the Irish Ireland movement" (1904, 7). The "Irish Ireland movement" was inspired by the foundation of the Gaelic League, an organization that aimed at fostering the revival of Irish language use in Ireland, as articulated by founder of the Gaelic League, Douglas Hyde, in his 1892 lecture on "The Necessity for De-Anglicising Ireland." Pearse draws attention to the fact that Arthur Griffith presents the case of Hungary to his Irish readers as one in which "the story of national revival [...] had its origins in a language movement" initiated by Count István Széchenyi's offer of his one-year land revenue at the Hungarian Diet in 1825 to further the cause of the Hungarian language in a country where the official languages had been Latin and German (1904, 7). Quoting Griffith on the matter, Pearse hails Széchenyi's achievements in the language revival movement, alongside those in the educational reform movement and in the furthering of industrialization in Hungary. Pearse described the Kingdom of Hungary at the beginning of the twentieth century as "free," "prosperous," and "renowned," and he was not alone in holding this view $(1904,7)$. Hungary was celebrating its Millennium at the end of the nineteenth century with countrywide events that reached all the main cultural capitals of Europe. At the time, the Austro-Hungarian Monarchy governed a large landmass, was a strong economic power, and exercised a significant influence on political matters in Europe, so the relationship between its constituent parts (Austria and Hungary) was closely examined by both scholars and politicians in Britain and Ireland in much the same way as was the relationship between Norway and Sweden, and Russia and Finland. The following essay examines the language revival and the educational reform movements in both Ireland and Hungary, arguing for a connection between the Irish and the Hungarian case, taking into account Arthur Griffith's ideas as communicated to his fellow Irishmen on the pages of The Resurrection of Hungary.

\section{Douglas Hyde, the Gaelic League, and the Irish Language Question}

Séamas Ó Buachalla explains the complicated situation that existed with regard to the use of the Irish language in Ireland when the Gaelic League was founded in the early 1890s: only a small percentage of the population used Irish as their first language and only a small number of schools taught Irish as a second language. Furthermore, argues Ó Buachalla, the National Board of Education, which was established by the British government in 1831, discouraged the teaching of the Irish language in the National School System, and the British government itself looked at the issue of Irish language use in schools with noticeable disfavour (1984, 75-78). This was so because of British government fears that encouraging the use of the 
Irish language would lead inevitably not only to rekindling Irish national feeling but also to re-igniting nationalist political sentiments throughout Ireland, where the population was divided along Irish/Catholic and British/Protestant lines.

This religious-political divide was an issue during the Home Rule negotiations of 1892-1893, during which period the Gaelic League was founded in July 1893. Prime Minister William Ewart Gladstone's Home Rule Bill of 1893 aimed to provide Ireland with a certain degree of legislative independence and intended to give the newly established Irish parliament the right to pass laws on certain areas of Irish life. On 25 November 1892, amidst this political debate about the future of Ireland within the United Kingdom, Douglas Hyde gave a lecture at a meeting of the Irish National Literary Society, the aforementioned "The Necessity for De-Anglicising Ireland." Hyde's lecture is considered to be the founding moment of the Gaelic League. On that momentous occasion, he said that Nationalists and Unionists should unite in "build[ing] up an Irish nation on Irish lines," should show interest in the old Gaelic literature of the land; and that "every Irish-feeling Irishman [...] should set himself to encourage the efforts, which are being made to keep alive our once great national tongue" (1892, 2-3). He also proclaimed that under the proposed new Home Rule government the Irish language should be on a par with other classical or modern languages in examinations, that children whose mother tongue was Irish should be taught in Irish, and that "Irish-speaking schoolmasters, petty session clerks, and even magistrates [should] be appointed in Irish-speaking districts" (1892, 3). Hyde finished his lecture with the following rousing statement: "because upon Irish lines alone can the Irish race once more become what it was of yore - one of the most original, artistic, literary, and charming peoples of Europe" $(1892,4)$.

Hyde's address to the Irish National Literary Society in 1892 should be understood and interpreted within a very particular discourse on nation and race in turn-of-the-century Britain and Ireland. This social and political discourse was encouraging both inclusion and exclusion: Hyde specifically called for the Irish people's rejection of what he termed "West-Britonism," meaning the obedient and unhesitating imitation of all things English $(1892,3)$. What is interesting in Hyde's speech from the point of view of language use is that in parts it reiterated some of the goals of an earlier Irish language campaign that was fought by the Society for the Preservation of the Irish Language back in the late 1870s. Hyde himself had been in touch with members of the Society who had sent a memorandum to the British government in 1878, signed by "most of the prominent figures in the public life of Ireland, irrespective of creed and denomination," with a request for the Irish language to be "placed on a similar footing to Latin, Greek and French [based on a variety of] cultural, academic, and political considerations" (Dunleavy and Dunleavy 1991, 75 and 106; Ó Buachalla 1984, 77). The Society did not achieve its goals, but the social and political discussion that the memorandum generated advanced the cause of bilingual education in Ireland: from 1878, Irish could be 
taught as an extra subject outside the regular school curriculum; from 1884, the number of Irish teacher trainees began to rise; and from 1893 the Gaelic League successfully encouraged wider educational reforms in Ireland. All of these combined efforts resulted in two new developments at the beginning of the twentieth century, both welcomed by the Gaelic League: the introduction of the New Programme for National Schools of 1900 and the Bilingual Programme of 1904 (Ó Buachalla 1984, 80). The Gaelic League had every reason to be satisfied with such progress, writes Ó Buachalla, because "the status of the Irish language in the national schools was [being] gradually raised," along the "native and autochthonous lines," as Douglas Hyde put it in his speech to the Royal Commission on University Education in 1902 (qtd. in Ó Buachalla 1984, 80).

\section{Patrick Pearse, St Enda's School, and Irish Educational Reform}

Patrick Pearse became a member of the Gaelic League in 1896 and took on the editorship of its bilingual journal, An Claidheamh Soluis, in 1903. He soon made a name for himself as someone who was passionate about the revival of the Irish language and the reformation of the Irish educational system. Pearse identified with the main aims of the League: "the preservation of Irish as a national language of Ireland," "the extension of its use as a spoken tongue," "the study and publication of existing Gaelic literature," and "the cultivation of modern literature in Irish" (National Library of Ireland 1916, 7). As the official leaflet of the League states, these were to be achieved through holding public meetings and lectures on the Irish language, running voluntary Irish classes; encouraging children to learn Irish songs, read Irish literature, and listen to Irish music; publishing and distributing books and pamphlets in Irish; collecting folk stories, poems, and riddles from the Gaeltacht districts in the west of Ireland; publishing the Gaelic Journal (National Library of Ireland 1916, 7). As a member of the Gaelic League, Pearse travelled to Belgium to examine the country's bilingual educational system in 1905, a visit that would leave a mark on his editorial contribution to An Claidheamh Soluis. Supported by Dr J. M. Starkie, who was Resident Commissioner of the National Board of Education in Ireland and staunch ally of the League in introducing the Bilingual Programme for National School of 1904, Pearse first travelled to the small town of Fontenoy in France to view the battle site where an Irish Brigade had fought in 1745 during the War of Austrian Succession (Augusteijn 2010, 149; Ingelbien 2016, 124). Pearse accompanied there the so-called "Fontenoy Committee:" Irish republican nationalists John O'Leary and Major John MacBride. He journeyed from here onto Belgium, where he visited a large number of primary and secondary schools, grace of the Ministry of Public Instruction in Belgium (Augusteijn 2010, 150). Pearse had 
been familiar with the Belgian system through T. R. Dawes's Bilingual Teaching in Belgian Schools, a book based on Dawes's visit to Belgian schools in 1899 as Gilchrist Travelling Student. Pearse saw the direct benefits of a well-functioning bilingual system in Belgium and, on his return to Dublin, he wrote a number of articles in An Claidheamh Soluis.

Elaine Sisson observes that Pearse was considered to be a "passionate and hardworking advocate" of the educational and language goals of the Gaelic League and that when he opened his own bilingual educational institution in Dublin in September 1908, there was a high level of "[o]ptimism for the success of the school" given "the reputation of the highly respected Pearse" (2005, 6-7). John Henry's editorial for An Claidheamh Soluis, published on 12 September 1908, remarked that Pearse's new school "will be a nursery of character, intellect, patriotism, and virtue, which may eventually exert a benign influence on the private and public life of our country" (qtd. in Sisson 2005, 6). Pearse's bilingual school, founded at Cullenswood House in Rathmines, was located in "the heart of south Dublin's prosperous Victorian suburbia" (O'Kane 2000, 73). Pearse had issues with the close proximity of Dublin and decided to move the school into the more remote area, near hayfields and grazing grounds: in Rathfarnham, County Dublin, he had found an eighteenth-century country house surrounded by acres of woods and parkland (O'Kane 2000, 73; Connell 2011, 66). Pearse's bilingual institution now became St Enda's School, and it opened its doors to students in September 1910. St Enda's was a liberal educational institution where children were encouraged to embrace their Irish heritage through dancing, singing, drawing, sculpting, and literature classes (Connell 2011, 66). Children were schooled in modern and classical subjects and were sent out to play the traditional Gaelic sports of hurling and football on the school grounds (Sisson 2005, 128-130). The language of instruction was Irish; only those subjects were taught in English which lacked the necessary vocabulary to be taught in Irish such as the main science subjects (Connell 2011, 66). St Enda's school's magazine, An Scolaire (The Scholar) was issued in Irish, and pupils participated in annual celebrations of mediaeval Irish culture both at Cullenswood House and at the Hermitage (Augustejn 2010, 172-173; Connell 2011, 66). Pearse himself wrote some of the plays and pageants performed by St Enda's players. Besides showcasing Pearse's own interest in the legendary tales of Cuchulain and Fionn MacCumhail, these adaptations should be considered as responses to Douglas Hyde's call to celebrate the old Irish material through the manner in which they were celebrated by nineteenth-century British and European scholars of Celtic literature. Hyde's "The Necessity for De-Anglicising Ireland" proposed that Irish men and women of letters should follow the renowned European Celticists Kuno Meyer, Ernst Wilhelm Oskar Windisch, and Marie Henri d'Arbois de Jubainville in celebrating the Celtic heritage of Ireland (1892, 3).

St Enda's pupils received an education that was unique at the time, through a school curriculum that made the most of what the bilingual educational reform could 
offer for Irish children at the beginning of the twentieth century. Ó Buachalla writes that under a new educational scheme introduced by Chief Secretary for Ireland Augustine Birrell in 1907 fee-paying schools were allowed to have their own bilingual educational programme $(1984,82)$. The scheme was welcomed by the Gaelic League and was put to good use at St Enda's under the watchful eyes of its Headmaster Pearse and its Second Master Thomas MacDonagh. Pearse scholars, however, draw attention to the fact that by the middle of the 1910s, the issue of reforming the Irish education system becomes intertwined in Pearse's reformist thought with the more pressing political matter of Ireland's cultural and political independence from Britain (Augusteijn 2010, Connell 2011, Sisson 2005, Walsh 2007). As Pearse elucidates in his essay on the failures of the British education system in Ireland, "The Murder Machine" (1913), he included the Irish legends in St Enda's curriculum in order to "re-create and perpetuate in Ireland the knightly tradition of Cuchulainn" (1916, 38). Although St Enda of the island of Inishmore (off the west coast of Galway), after whom the school was named, was the leading light of mediaeval monasticism in Ireland, it was not the practice of silent contemplation that the school's pupils learned during their daily routine. Their daily study of the heroic behaviour of mediaeval Irish knights and warriors, such as Cuchulain and Fionn McCumhail, instilled in them an honour code that drew them to the call of Ireland in times of rebellion: St Enda's pupils fought alongside Pearse, their teacher, at the General Post Office (GPO) during the Easter Rising of April 1916. Pearse noted at the end of the first day of the Rising, Easter Monday, 23 April 1916: "[t]he St. Enda's boys have been on duty on the roof [of the GPO] since we came in," adding that "[t]hey are all in excellent spirits although very sleepy" (qtd. in Ryan 1960, 89). The fears of the Commissioners of National Education back in the early 1830s - that the Irish language movement would rekindle separatist nationalist sentiments in Ireland - became a political reality on the occasion of the Easter Rising. However, it must be noted that it was not the language movement itself that led to a rebellion against British rule in Ireland but rather the widespread militarization of the island from the early 1910s onwards, the postponement of the enactment of the Home Rule Bill passed by both the House of Commons and the House of Lords in 1914, and the outbreak of the Great War in the summer of 1914. During the war, Irishmen were called upon to join the British imperial army to go into battle on the European Continent.

\section{Arthur Griffith, Language Revival, and The Resurrection of Hungary (1904)}

Owen McGee writes that when The Resurrection of Hungary: A Parallel for Ireland first came out in a serialized form in the United Irishman newspaper in 1904, Arthur Griffith suddenly found himself at the centre of Dublin's influential literary 
and professional circles that were discussing the political future of Ireland (2015, 69). Griffith argued vehemently that Ireland should seek a similar political contract with Great Britain that Hungary had signed with Austria in 1867. Griffith reasoned as follows: since the Ausgleich of 1867, Hungary had "outstripped the majority of European countries” in both material progress and cultural achievement and had established the Hungarian language as the official language of the state, "used in all state documents, in all courts of law and [...] in public offices" (1904, 77 and 73). Griffith returned to the question of language revival on a number of occasions during the run of his articles, stating that there was a direct connection between the achievements of the language revival, the intensification of national feeling, and the increase of Hungary's economic productivity after the Ausgleich (1904, 80). Griffith decided to present the case of Hungary as an example for Ireland, asserting that " $[\mathrm{t}$ ]o-day we are fighting precisely the same fight in Ireland as the Hungarians did in the early Forties," drawing a parallel between the Ireland of his time and the Hungary of the Reform Era $(1904,80)$. Pearse was aware of Griffith's interest in the Irish language movement though his countryman would have taken different sides to the Gaelic League on the non-political end of the language revival. Pearse knew that Griffith had high hopes for the national revival in Ireland, writing in his review of The Resurrection: "[he] enunciates with regard to political nationality the truth which the Gaelic League enunciates with regard to spiritual nationality: that the centre of gravity of a nation must be within the nation itself" $(1904,7)$. Given Griffith's conviction on the matter and Pearse's involvement in the "Irish Ireland movement," it is little wonder that Pearse concluded his editorial with the following words: "[t]the moral of the whole story is that the Hungarian language revival of 1825 laid the foundation of the great, strong and progressive Hungarian nation of 1904. And so it shall fall out in Ireland” (1904, 7).

As mentioned, Griffith identified Count István Széchenyi as the initiator of the Hungarian language movement with the offer of his one-year land revenue to found the National Academy of Sciences at the Diet of 1825-27 (1904, 14). Griffith cites Széchenyi's legendary speech given on 3 November, the opening day of the parliamentary session, in response to Pál Felsőbüki Nagy's powerful exposé on land, taxation, and language reform. As the story goes, Széchenyi listened to Felsőbüki Nagy's speech and then made the offer to fund the establishment of a Hungarian Tudós Társaság (Society of Scholars). The Society later took the name "Academy" and had an impressive palace built near the Chain Bridge, on the left bank of the Danube. Griffith presents Széchenyi in glowing terms: he was a true patriot, the "leader of the nation," aware of "his country's needs" and "equipped by study, observation, and character" to help her build a more prosperous future $(1904,15)$. Griffith writes that the following advice Széchenyi had given to his countrymen summarizes the Count's teachings: "[r]evive your language, educate yourselves, build up your agriculture and your industries" (qtd. in Griffith 1904, 15). There was truth in what Griffith 
wrote about Széchenyi's influence in Hungary: he and his countrymen initiated countrywide railway and waterway building projects; the running of steam boats and steam trains on railways and waterways; the re-introduction of horse breeding and horse racing; and new construction of bridges, especially that of the suspension bridge over the Danube (which later came to be known as "the Chain Bridge").

Thomas Kabdebó remarks that part of Griffith's admiration of Széchenyi may well have derived from a direct connection to the Irish separatist nationalist movement of the mid-nineteenth century: William Smith O'Brien, one of the leaders of the failed Young Ireland rebellion of 1848, visited the Hungarian Diet held in Buda in 1861 (2001, 26). There he listened with admiration to a famous speech of Ferenc Deák declaring the law-making autonomy of the parliament - he would later orchestrate the Ausgleich of 1867 and would be praised for doing so by Griffith. As Kabdebó discovered, William Smith O'Brien's guide for the first part of his visit to the city was Count Széchenyi’s son, Count Béla Széchenyi $(2001,26)$. However, in The Resurrection, Griffith intended more than merely to celebrate Széchenyi as "the greatest Hungarian," as he had come to be known in Hungary. His intention was to encourage his fellow Irish countrymen and women who were involved in various revival movements at the turn of the twentieth century, offering the Hungarian example as a model of what could be achieved. Critical as he often was of the various Irish organizations and their members (devastatingly so in the case of Dublin's Abbey Theatre), Griffith still saw great value in the work of Douglas Hyde and Patrick Pearse for the Gaelic League; that of Horace Plunkett and George Russell for the Co-operative Movement; and that of Lady Augusta Gregory, John Millington Synge, and William Butler Yeats for the Irish Literary Revival. Griffith realized that the social, cultural, and educational programmes they were trying to implement in Ireland had every potential to bear the same fruits as "Széchenyi's programme." It was this belief that led him to support Pearse's candidacy for the editorship of $A n$ Claidheamh Soluis in 1903 (Augusteijn 2010, 101).

One Hungarian who is given little attention in Griffith's celebratory work of Hungary is Baron József Eötvös, member of the Magyar Tudós Társaság (Hungarian Society of Scholars), President of the Hungarian Academy of Science, and Minister of Education and Religious Affairs (1848 and 1867-72). Eötvös and Széchenyi differed significantly in their views as to the end of the language revival and the aim of an educational reform. Széchenyi held the view that, first and foremost, the Hungarian language should be made suitable for verbalizing and interiorizing the new scientific achievements of the industrial age, paving the way for the country's economic growth and future industrial progress. Contrary to the "Széchenyi legend," it was for this reason that he had offered his one year's land revenue for the establishment of the Magyar Tudós Társaság. Further to this, he believed that the material progress facilitated by the language movement would lead to more political rights being secured for Hungary within the Habsburg Empire. Széchenyi 
feared that should the education system be reformed first, it would lead to a scenario in which large masses of enlightened people would call fervently for more civic and communal rights, possibly resulting in serious social unrest or even rebellion (Bényei 1996, par. 6). Eötvös, on the other hand, argued that educational reform was essential for economic progress to take place, maintaining that the education and cultivation of the population would eventually lead to the people of Hungary acquiring more political rights (Bényei 1996, par. 6 and 8-9). Eötvös did not share Széchenyi's concerns that there was no point in discussing educational matters at parliamentary sessions so long as final decisions lay with the Habsburg monarch and him averse to reforms, in fear of undermining his political power as Head of the Habsburg Empire (Bényei 1996, par. 7). Eötvös, therefore, pushed ahead with the programme of making the Hungarian language the official language of the country, a move that contributed to a wider nation-building project on which the Hungarian liberal political élite had embarked at the beginning of the nineteenth century. Partly as a result of his efforts, Hungarian language classes were made compulsory in elementary schools from 1843 onwards and the Hungarian language was declared the official language of Hungary in 1844.

Miklós Bényei reminds us that one of Eötvös's aims was to create "national unity" by means of education, convinced that, in the long run, only this could secure Hungarian control over social and political affairs in a multicultural and multinational country, only half of its population being Magyar (Bényei 1996, par. 10). Benedict Andersen and Joep Leerssen write about systematic and enforced "Magyarization" of all the minorities living on the territory of the Kingdom of Hungary during the nineteenth century (Andersen 1982, 101-106; Leerssen 2008, 154-156). There is truth in these critical comments, in that the "de-Germanization of Hungary" - long preceding Douglas Hyde's call for the "de-Anglicization of Ireland" - meant the strengthening of the political influence of the Hungarian language in the Carpathian Basin. However, the situation was more complex than Andersen and Leerssen present it in their influential critical studies on the emergent nationalist movements in Europe. First, nineteenth-century Hungarian history involved many different phases: the final period of Habsburg absolutism in the early nineteenth century, the reform era of the 1820s-1840s, the revolution of 1848-49, the post-revolutionary oppression (including the Bach era) from 1849 to 1866, and the decades of the Dual Monarchy from the Ausgleich of 1867 until the end of the century. Over the course of this turbulent century in Hungary's history, the question of education was riven by the often rivalrous interests of the Habsburg monarch, the Hungarian nobility, the Roman Catholic Church in Hungary, and the different ethnic minorities such as the Croatians, the Serbians, the Saxons, and the Romanians (Dobszay 2003, Pajkossy 2003, Csorba 2003).

Second, this multicultural and multi-ethnic population of nineteenth-century Hungary was divided along many different confronting and/or correlating lines, 
not just along the oft-cited ethnicity/minority (nemzetiségi) line (Dobszay 2003, 163 and 167). Out of these, the division along class (rend) lines was the strongest, often matching the ethnicity/minority line as in the case of the Saxons and the Serbians (Nagy and Katus 2010,4). Quite understandably, the more prosperous an ethnic minority had become, the more it held onto its communal rights (közösségi jog) such as the right to use its own language and run its own educational institutions. Nagy and Katus remark that the "nation-building" of the various ethnic minorities in the region was taking place simultaneously with the larger "political nation building project" envisaged by the Hungarian social and political élite and that they were successful in preventing the hegemony of the Hungarian language in the Carpathian Basin until the 1890s (2010, 4-11). Finally, there was the issue of religious affiliation and the power of the various "official churches" (hivatalos egyház), each of which had the right to run their own educational institutions in which children were taught in the language of the religious denomination/ethnic minority that financed the school (see articles 38 and 44 in the minority and education legislation of 1868; Nagy and Katus 2010, 15). For instance, the Serbian Orthodox Church, the Romanian Orthodox Church, and the German Lutheran Church were recognized as "official churches," and in various parts of Hungary these churches had the right to choose the language of instruction in their educational institutions. Eötvös's aspiration to the use of the Hungarian language in the new "political nation" post-Ausgleich did not mean the enforced ending of bilingual, or in some cases trilingual, education of children in certain parts of the Kingdom of Hungary. Curiously, professor of Celtic languages Kuno Meyer, who had received treatment in the thermal baths of Pöstyén in the Slovakian territory of Northern Hungary, wrote in a letter to Gaelic League founder Douglas Hyde that the people of Pöstyén were fluent in three languages: Slovak, Hungarian, and German (Ó Cróinín 2016, 37). Meyer's correspondence with Hyde in 1904 and 1905 is indicative of their shared interest in the Hungarian language movement of the nineteenth century, in particular in the foundation of the Hungarian Academy, with Meyer promising to acquire the statute of the Hungarian Academy to provide example for the foundation of what he tentatively called the "Irish Academy," or "Academy of Irish Learning” (Ó Cróinín 2016, 37-38). Pearse refers to Meyer’s address to the Gaelic League in Liverpool in 1904, entitled "The Need of an Irish Academy," in his editorial in An Claidheamh Soluis as one to follow on further parallels between the language movements of Ireland and Hungary $(1904,7)$.

\section{Language Reform and Hungarian Millennialism}

One of the issues not addressed in Griffith's The Resurrection of Hungary was the manner in which the Hungarian language had been reformed in the nineteenth century. Since the last decades of the eighteenth century, prominent priests, 
poets, and encyclopaedists had been urging a more extended use of the Hungarian language, but their efforts had been crushed by the Austrian absolutist political élite, who feared that any concession towards broadening Hungarian language use would lead to the strengthening of the national identity of Hungarians. Similar arguments would resurface in the British Government's disregard and/or disfavour of the use of the Irish language during the 1830s and 1840s. As concessions began to be offered at the Habsburg court in Vienna towards the Hungarians during the 1820s and 1830s, however, a serious debate started to unfold between neologists and ortologists with regard to the way in which the Hungarian language should be revived. Neologists (or reformists) believed that a standardized new linguistic corpus should be created by means of derivation, suffixation, and word invention, one that would serve the widening linguistic needs of a country undergoing an industrial revolution. Ortologists (or revivalists) maintained that the language movement should work towards preserving the wide variety of dialects that existed in the Carpathian Basin, enriching the language with the linguistic diversity in the long term (Dobszay 2003, 170-174). Similarly in Ireland at the turn of the twentieth century, progressivists and nativists clashed over the manner of the revival of the Irish language. O'Leary writes that the debate between nativists and progressivists went on for a good while on the pages of An Claidheamh Soluis in the late 1900s and that, while nativism was a strong strain within the Gaelic League, progressivism was still a "fundamental element in the league's programme" because it was understood that both language and literature "must confront the realities of twentieth-century European life" (1994, 233). As this happened in Ireland in the early twentieth century, so it happened in Hungary in the early nineteenth century: the debate about the future of the Irish and the Hungarian languages was won by those who argued for the creation of a new, logical, and more scientifically assured linguistic corpus that would meet the needs of political, religious, social, and literary discourse. This argument was won in the hope that both early-nineteenth century Hungary and early twentieth-century Ireland might achieve significant economic development.

Returning to Baron Eötvös's aforementioned calls for the extended use of the Hungarian language within the new Kingdom of Hungary post-Ausgleich: he held that the newly-formed Hungarian "political nation" (politikai nemzet) should use the newly-reformed Hungarian language as it would serve the needs of trade, industry, and agriculture better than the old-fashioned languages of German and Latin that had been the official languages of the Habsburg Empire during the long eighteenth century. Griffith, for his part, paid littleattention to the nuances of the language reform movements either in Hungary or in Ireland despite the incredible amount of background research he had done in preparation for writing The Resurrection of Hungary: A Parallel for Ireland. Griffith's intentions could be better understood when considered in relation to the Millennial Celebrations that were held around the Kingdom of Hungary from the mid-1890s onwards. On the one hand, these country-wide celebrations were conceived 
by the social and political élite as the culmination of the Hungarian nation-building project of the latter half of the nineteenth century, celebrating the Hungarian presence in the Carpathian Basin during the previous one thousand years. On the other hand, the events were used to showcase contemporary artistic talent in the fields of music, painting, sculpture and architecture, living and working in post-Ausgleich Hungary. At the time, museums, music halls, and theatre houses were built and construction work was underway on the new Houses of Parliament on the Danube, with doors opening in 1892 and construction completed in 1904, the year of publication of The Resurrection. News of the Millennial Celebrations had reached Ireland in forms of newspaper articles and journal reviews as well as in forms of art shows such as the one that exhibited Mihály Munkácsy's award-winning Ecce Homo (1896) at the Royal Hibernian Academy in Dublin in 1899. Tekla Mecsnóber noted that James Joyce had seen the Munkácsy exhibition at the Royal Irish Academy and had written an essay on his artistic impressions of Ecce Homo (2001, 347). This is most intriguing given that Griffith's biographer, Owen McGee, draws a direct link between Joyce and Griffith: "Ultimately, Joyce's experimental novel Ulysses (Paris 1922) would be set in Dublin on the same day (16 June 1904) as the last of Griffith's 'Resurrection of Hungary' articles appeared in the United Irishman" $(2015,70)$. Within this Millennial context, Griffith's editorial/pamphlet should be considered as a "Millennial text;" similar in vein to Joseph de Jekelfalussy's edited volume, The Millennium of Hungary and Its People, a book that was attached to the Millennial National Exhibition of 1896 held in Budapest. The Resurrection of Hungary was not just the inaugurating publication of the political party Sinn Féin (Ourselves Alone), which Griffith founded in 1905; it was also a contribution to the Millennial Celebrations that were held in Hungary and in other parts of Continental Europe.

\section{Conclusion}

Pearse recommended that every member of the Gaelic League buy Griffith's pamphlet and "study it for himself" $(1904,7)$. Griffith himself wrote that there was a hint in it for the Gaelic League, especially with regard to the way the "Irish Ireland movement" was to evolve in the decades ahead $(1904,82)$. Griffith mentioned enthusiastically the establishment of a national press in Hungary, reporting on all areas of life from sport to women's fashion, the building of a National Theatre and a National Museum in Buda-Pest, the foundation of the Hungarian Academy and the National University, and, finally, the filling of bookshops with Hungarian works of literature (1904, 80-82). As advocate of the revival of the Irish language in Ireland, Pearse found Griffith's ideals regarding the successful "resurrection" of the Hungarian language in all areas of Hungarian life most intriguing. One area where Griffith revealed little in his study of parallels between Ireland and Hungary was that of 
education, but Pearse here turned to the ideals of the "Irish Ireland movement" of the Gaelic League. With the foundation of St Enda's School, Pearse realized one of the main aims of the movement: bilingual education of Irish children, schooling them to embrace their Irish-language heritage. St Enda's was an experiment in education and cultivation, a realization not only of Pearse's educational ideals but also of his social and political thought. Griffith's political ideals differed significantly from Pearse's political thought, especially as Pearse began to embrace, and disseminate in public, a more radical, revolutionary ideology in the mid-1910s. Pearse and Griffith agreed that the "whole national life" of Ireland could be revived and rejuvenated through the Irish language movement in much the same way as it had occurred in nineteenthcentury Hungary through the Hungarian language movement (Pearse 1904, 7). Hyde was perhaps keener on promoting the use of the Irish language in schools and public life and on rediscovering the old legends of Ireland preserved in mediaeval Irish manuscripts than actively promoting either a radical or a more moderate political view during the 1890s and 1900s. Still, when the time had come, all of them took an active role in Irish politics: Patrick Pearse read out the Proclamation of the Irish Republic on behalf of the Provisional Government, and as Commander-in-Chief, during the Easter Rising in April 1916; Arthur Griffith was one of the signatories of the Anglo-Irish Treaty of 1921 that established the Irish Free State, and he acted as President of Dáil Éireann, putting together the Provisional Government of 1922; and, finally, Douglas Hyde was made first President of Ireland in 1938, following the enactment of the Constitution of Ireland in 1937. At one point in their lives, each of these ideologists and politicians considered nineteenth-century Hungary as a model for Ireland to follow in building a more successful and more prosperous future for the country as it entered into the first decades of the twentieth century.

\section{Works Cited}

Anderson, Benedict. 1982. Imagined Communities. London: Verso.

Augusteijn, Joost. 2010. Patrick Pearse: The Making of a Revolutionary. Basingstoke: Palgrave Macmillan.

Bényei, Miklós. 1996. Eötvös József könyvei és eszméi [József Eötvös’s Books and Reflections]. Debrecen: Csokonai. https://mek.oszk.hu/03100/03176/html/ eotvos23.htm (last accessed: 1 June 2020).

Connell Jr., Joseph E. A. 2011. "Countdown to 1916: St Enda’s School/Scoil Éanna." History Ireland vol. 19, no. 3 (May/June): 66.

Csorba, László. 2003. "Az önkényuralom kora (1849-1867)” [“The Age of Austrian Autocracy (1848-1867)”]. In Magyarország története a 19. században [The History of Hungary in the Nineteenth Century], ed. András Gergely, 279-326. Budapest: Osiris. 
Dobszay, Tamás. 2003. “A művelődés és a műveltség polgárosodása” [“Culture and the Rise of the Middle Class”]. In Magyarország története a 19. században [The History of Hungary in the Nineteenth Century], ed. András Gergely, 154-190. Budapest: Osiris.

Dunleavy, Janet Egleson and Gareth W. Dunleavy. 1991. Douglas Hyde: A Maker of Modern Ireland. Berkeley/Los Angeles: University of California Press.

Griffith, Arthur. 1904. The Resurrection of Hungary: A Parallel for Ireland. Dublin: Duffy, Gill, Sealy, Bryers and Walker.

Hyde, Douglas. 1892. "The Necessity for De-Anglicising Ireland." https://www. thefuture.ie/wp-content/uploads/1892/11/1892-11-25-The-Necessity-for-DeAnglicising-Ireland.pdf (last accessed: 1 June 2020).

Ingelbien, Raphaël. 2016. Irish Cultures of Travel: Writing on the Continent, 18291914. Basingstoke: Palgrave Macmillan.

Jekelfalussy, Joseph de. 1897. The Millennium of Hungary and Its People. Budapest: Pesti Könyvnyomda Részvénytársaság.

Kabdebó, Thomas. 2001. Ireland and Hungary: A Study in Parallels. Dublin: Four Courts Press.

Leerssen, Joep. 2008. Nationalist Thought in Europe: A Cultural History. Amsterdam: Amsterdam University Press.

McGee, Owen. 2015. Arthur Griffith. Dublin: Merrion Press.

Mecsnóber, Tekla. 2001. "James Joyce, Arthur Griffith, Trieste, and the Hungarian National Character.” James Joyce Quarterly vol. 38, no. 3/4, Joyce and Trieste (Spring/Summer): 341-359.

Nagy, Marianna and László Katus. 2010. “A Magyar Korona országainak nemzetiségei a 18-19. században” ["Minorities in the Kingdom of Hungary in the Eighteenth and Nineteenth Centuries"]. Árkádia. Pécsi Tudományegyetem. http://arkadiafolyoirat.hu/images/000_tortenelem/TOR001_TAN_nagy-katus. pdf (last accessed: 10 July 2020).

National Library of Ireland. 2016. The 1916 Rising: Personalities and Perspectives. Dublin: National Library of Ireland.

Ó Buachalla, Séamas. 1984. "Educational Policy and the Role of the Irish Language from 1831 to 1981.” European Journal of Education vol. 19, no. 1, Multicultural Education: 75-92.

Ó Cróinín, Dáibhí. 2016. "Letters of Kuno Meyer to Douglas Hyde, 1896-1919.” Studia Hibernica vol. 42: 1-64. Online available at ARAN, NUI Galway: https:// aran.library.nuigalway.ie/bitstream/handle/10379/7183/Meyer-Hyde\% 20 Letters \%20\%284.0\%29.pdf?sequence=5\&isAllowed=y (last accessed: 1 July 2020).

O’Kane, Finola. 2000. "Nurturing a Revolution: Patrick Pearse’s School Garden at St Enda's.” Garden History vol. 28, no. 1: Reviewing the Twentieth-Century Landscape (Summer): 73-87. 
O'Leary, Philip. 1994. The Prose Literature of the Gaelic Revival, 1881-1921: Ideology and Innovation. Pennsylvania: Pennsylvania State University Press.

Pajkossy, Gábor. 2003. “A reformkor 1830-1848” [“The Reform Era, 1830-1848”]. In Magyarország története a 19. században [The History of Hungary in the Nineteenth Century], ed. András Gergely, 191-233. Budapest: Osiris.

Pearse, Patrick, 1904. "Hungary and Ireland." An Claidheamh Soluis vol. 6, no. 38 (26 November): 7.

1916. Collected Works of Pádraic H. Pearse: Political Writings and Speeches. Dublin: Phoenix Publishing.

Ryan, Desmond. 1960. “St. Enda's: Fifty Years After.” University Review vol. 2, no. 3/4, Jubilee Issue (Autumn/Winter): 82-90.

Sisson, Elaine. 2005. Pearse's Patriots: St. Enda and the Cult of Boyhood. Cork: Cork University Press.

Walsh, Brendan. 2007. The Pedagogy of Protest: The Educational Thought and Work of Patrick H. Pearse. Bern: Peter Lang. 